\title{
DUAL EDUCATION AS THE PECULIARITY OF SPECIALIZED TRAINING OF NURSING PERSONNEL IN GERMANY
}

\begin{abstract}
Specialized training of nursing personnel in Ukraine is being reformed presently. Quality specialized training of nursing personnel is a prerequisite for successful functioning of the health care system in general. In this regard, the article describes dual education system in Germany where educators have accumulated valuable experience in specialized training of nursing personnel. It must be noted that dual education system is divided into theoretical and practical components, whereas theoretical component assumes out-service training and priority practical component - in-service training. In addition, such notions as "dual education", "nursing personnel", "professional training", "specialized training" have been defined. The peculiarities of specialized training of geriatric nursing personnel, health and nursing professionals, health and pediatric nursing personnel have been considered. Special attention has been paid to the fact that new names for nursing professions linguistically highlight a more extensive approach to nursing. The role of practice mentoring in specialized training of nursing personnel has been justified. Based on theoretical analysis of references, it has been concluded that professional pedagogics being the most developed direction in Germany contributes to efficient organization of the education process and training of highly qualified specialists.
\end{abstract}

Keywords: dual education, law, practical training, nursing personnel, system, theoretical training, specialized training, Germany.

\section{INTRODUCTION}

Quality specialized training of nursing personnel is the key to successful functioning of the health care system in general. Unfortunately, the health care system in Ukraine lacks medical personnel, including nursing personnel. However, specialized training of nursing personnel in Ukraine is being reformed, so it is hoped that it should be on the verge of positive changes.

According to the requirements of the World Health Organization (WHO), in particular the European Bureau (EB) and the International Council of Nurses (ICN), the minimum number of hours for a three-year training shall be 4600 , covering theoretical and practical training. Practical training should comprise at least $50 \%$ of the total training time. Specialized training of nursing personnel in Germany meets these requirements, so it is of particular interest for our study (Verkhovna Rada Ukrainy, 2017).

\section{THE AIM OF THE STUDY}

The aim of the study is to analyze and reveal the main peculiarities of specialized training of nursing personnel in Germany.

\section{THEORETICAL FRAMEWORK AND RESEARCH METHODS}

Theoretical analysis of scientific-pedagogical literature proves the interest of many scholars in Ukraine and Germany in the problems of forming and development of 
professional education in Germany, including medical education. Development of the education system in Germany has been studied by such native researchers as N. Abashkina, V. Bazova, O. Dmytrenko, T. Kozak, S. Sysoieva. The fundamental basis for specialized training of nursing personnel in Germany consists of researches on professional training by such German scholars as M. Baethge, J. Baumert, K. Cortina, J. Pahl, H. Schanz, R. Weiß. Theoretical and practical aspects of specialized training of nursing personnel in Germany have been covered in the papers by B. Herzberg, S. Löffert, U. Oelke, K. Sahmel, P. Steffen, M. Zöller.

It should be noted that the essence of specialized training of nursing personnel in Germany has not been sufficiently studied by Ukrainian scholars yet. In addition, the peculiarities of specialized training of nursing personnel in Germany have not been revealed in Ukrainian psycho-pedagogical literature.

To achive the aim of the study we have used the following methods: a comparative analysis of the works by native and foreign researchers, normative legislative documents, electronic resources on the problem under study; synthesis, generalization and systematization of theoretical provisions contained in the above-mentioned specialized sources.

\section{RESULTS}

The high level of the German economy, its government policy and branching network of enterprises provide practical training for those pursuing professional education based on a great number of different enterprises. Vocational training schools (Berufsbildende Schule) has several varieties, which include (part-time) vocational school (Berufsschule), (full-time) specialized vocational school (Berufsfachschule), vocational further school (Berufsaufbauschule), upper vocational school (Berufsoberschule), vocational gymnasium (Berufliches Gymnasium) and specialized upper secondary school (Fachoberschule) (Dmytrenko, 2013; Kozak, 2011; Wikipedia, 2017; Bundeszentrale für politische Bildung, 2017).

According to a variety of education institutions and training processes, the system of professional education in Germany is structurally divided into three sectors, namely, dual (das duale System), school-based vocational training (das Schulberufssystem) and transition systems (das Übergangssystem) (Cortina, Baumert \& Leschinsky, 2008).

It is well known that the education system in Germany is also regulated by the Standing Conference of the Ministers of Education and Cultural Affairs of the Länder in the Federal Republic of Germany (Kultusministerkonfernz - KMK) and the German Rectors' Conference (Hochschulrektorenkonferenz - HRK). Locally, the education process is regulated by the Land Ministries (Sysoieva \& Krystopchuk, 2012).

The main normative legislative documents regulating the professional education functioning in Germany comprise the "Regulation on Professional Education" ("Ausbildungsordnung"), developed by the Federal Government for each state-recognized occupation (profession), Protection of Young Persons Employment Act ("Jugendarbeitsschutzgesetz") as of April 12, 1976 and "Vocational Training Act" ("Berufsbildungsgesetz") as of August 14, 1969 (last updated on March 23, 2005; last amended on April 5, 2017). It is the basis of vocational education and training and determines the mutual relations, educational approaches and other legal matters (Bundesinstitut für Berufsbildung, 2014; Bundesministerium der Justiz und für Verbraucherschutz, 2012).

Dual system of professional training is the object of our attention, as more than $50 \%$ of secondary-school leavers in Germany choose one of 350 state-recognized occupations (staatlich anerkannte Ausbildungsberufe) just within the dual education system (Wikipedia, 2017). 
According to the data analyzed, the dual education system was first introduced in Germany in the 1960s and its founder is considered to be G. Kerschensteiner. The concept of dual education (duales Studium) is viewed as a combined model of professional education organization, that is divided into theoretical and practical components, whereas theoretical component assumes out-service training and priority practical one - in-service training (Wikipedia, 2017).

The peculiarity of dual education, as opposed to purely academic, is that priority practical training (3-4 days) takes place at the enterprise and theoretical one (1-2 days) - in the training school during a week. The interconnection between enterprises and training schools during a 2-3,5-year training ensures preparation of craftsmen and highly qualified specialists. In addition, dual education system enables young people to improve their skills and is an important step in their career growth (Tatsachen über Deutschland, 2017).

In order to further use the term "specialized training" ("Fachausbildung") in the paper, it is necessary to apply to Duden - German explanatory dictionary. It interprets the term as "professional training, specialized in a particular area" ("Fachausbildung berufliche Ausbildung in einem bestimmten Fach"). The term "professional training" ("Berufsausbildung") is defined as "training a particular profession" ("Berufsausbildung Ausbildung für einen bestimmten Beruf") (Duden, 2017).

To comprehend the system of nursing personnel's specialized training in Germany, one should first clarify the concept of "nursing personnel". The 1977 "Convention concerning Employment and Conditions of Work and Life of Nursing Personnel" (No 149) states that "nursing personnel means all categories of persons providing nursing care services" (Verkhovna Rada Ukrainy, 1977).

However, in Duden the term "nursing personnel" ("Pflegepersonal") is interpreted as "personnel working in a hospital, nursing home or similar nursing establishments" ("Pflegepersonal - Personal, das in einem Krankenhaus, Pflegeheim o. ä. in der Krankenpflege tätig ist”) (Duden, 2017).

It must be noted that the term "nursing personnel" in Germany covers quite a large list of nursing professions, such as a geriatric nurse $(\mathrm{m} / \mathrm{f})$ (Altenpfleger/-in). Beginning from January 1, 2014, new names for professions include a health and nursing professional $(\mathrm{m} / \mathrm{f})$ (Gesundheits- und Krankenpfleger/-in), a health and pediatric nurse (m/f) (Gesundheits- und Kinderkrankenpfleger/-in). These professions are state-recognized and their list can be found in the Classification of Occupations 2010 (Klassifikation der Berufe Kldb-10). Unlike Ukrainian, the German classification distinguishes gender (Bundesagentur für Arbeit, 2010; 2017).

It is advisable to pay attention to the fact that the new names for nursing professions linguistically highlight a more extensive approach to nursing. The characteristic of nursing professions is not limited to the medical aspect and also includes prevention, rehabilitation and palliation. Training is not limited to a certain group of people and includes care for patients of all ages (Steffen \& Löffert, 2010).

Beginning from January 1, 2018, Germany is planning to reform medical nursing education. Specialized training of above-mentioned nursing personnel is expected to be united. According to the "Legislative Draft on Reforming Nursing Professions" ("Entwurf eines Gesetzes zur Reform der Pflegeberufe - Pflegeberufereformgesetz"), which is being viewed by the Parliament of Germany, there should appear a new name for nursing personnel, namely, a nursing care specialist (Pflegefachfrau/Pflegefachmann). 
Within this paper, we would like to analyze specialized training of geriatric nurses, health and nursing professionals, health and pediatric nurses. Vocational Training Act ("Berufsbildungsgesetz") as of March 23, 2005, with the recent amendments as of April, 5, 2017, does not regulate their training, as the total number of training hours (1440) indicated in it does not match those hours (4600) designated for nursing personnel training.

Specialized training of nursing personnel and their practical activities in Germany are now regulated by the "Geriatric Nursing Act" ("Altenpflegegesetz") as of November, 17, 2000 (last amended on April, 18, 2016), the "Regulation on Geriatric Nursing Education and Examination" (Altenpflege-Ausbildungs- und Prüfungsverordnung) as of November, 26, 2002 (last amended on April 18, 2016), "Nursing Act" ("Krankenpflegegesetz") as of July 16, 2003 (last amended on April 4, 2017), the "Regulation on Nursing Education and Examination" (Ausbildungs- und Prüfungsverordnung für die Berufe in der Krankenpflege) as of November 10, 2003 (last amended on April 18, 2016) and others. According to these regulations, specialized training of geriatric nurses, health and nursing professionals, health and pediatric nurses covers 4600 hours, including 2100 hours designated for theoretical and practical studies and practical training -2500 hours (Bundesministerium der Justiz und für Verbraucherschutz, 2002; 2003).

According to the "Regulation on Nursing Education and Examination", the total number of hours (2100) designated for theoretical and practical studies cover such relevant topics as pediatric and geriatric health and care, nursing and health sciences (950); natural sciences and medicine (500); humanities and social sciences (3000); law, politics and economics (150); options (200) (Bundesministerium der Justiz und für Verbraucherschutz, 2003).

Theoretical studies are not limited to mere knowledge transfer and are aimed at presenting many stages of the nursing process. While learning, future specialists improve their practical abilities and skills in nursing care, bandaging, wound care, administering medications, patient feeding.

Practical training consists of three stages and takes place not only in hospitals but also in relevant out-patient and in-patient facilities, rehabilitation centers. The first stage starts with a general part (1300 hours), which is the same for everyone. The second one is characterized by differentiation and specialization of training of health and nursing professionals, health and pediatric nurses ( 700 hours). The third one (500 hours) is based on differentiated distribution of practical training of health and nursing professionals, health and pediatric nurses. The general part of practical training includes prevention and inpatient care for patients of all ages in surgery, internal medicine, geriatrics, gynecology, neurology, pediatrics, care for obstetric patients and infants as well as rehabilitation and palliative care ( 800 hours); prevention and out-patient care for patients of all ages (500 hours) (Bundesministerium der Justiz und für Verbraucherschutz, 2003).

Differentiated training takes place only in stationary facilities. There future health and nursing professionals, health and pediatric nurses study different disciplines, namely, future health and nursing professionals master internal medicine, surgery, psychiatry (700 hours); health and pediatric nurses - pediatrics, neonatology, pediatric surgery, pediatric neurology, child and adolescent psychiatry (700 hours) (Bundesministerium der Justiz und für Verbraucherschutz, 2003).

Specialized training of geriatric nursing personnel covers a period of three years with at least 2500 hours of practical training. 2100 hours of theoretical and practical studies are designated for the subjects listed in Annex 1 of the "Regulation on Geriatric Nursing Education and Examination". 
Theoretical and practical studies in geriatrics are distributed as follows: tasks and concepts of geriatrics (1200 hours); assistance to the elderly in organizing their daily life (300 hours); general legal and organizational working conditions of the elderly (160 hours); geriatrics as a profession (240 hours); options (200 hours).

At least 2000 hours of practical training should be allocated to in-service training at the facilities specified in the "Geriatric Nursing Act" (paragraph 4). Such facilities include asylums and out-patient nursing homes. In addition, a certain period of training (500 hours) can take place in psychiatric clinics, somatic hospitals with geriatric departments, geriatric rehabilitation centers, geriatric homes (Bundesministerium der Justiz und für Verbraucherschutz, 2003; 2000).

Specialized training of health and nursing professionals, health and pediatric nurses lasts three years (full-time). For those who study part-time, the period of specialized training covers up to 5 years. Training is considered to be successfully completed after state examinations have been passed (Bundesministerium der Justiz und für Verbraucherschutz, 2000; 2014).

According to the "Nursing Act", joint training of health and nursing professionals, health and pediatric nurses lasts two years (full-time). Next follows differentiation toward general health and nursing care or health and pediatric nursing that lasts a year (500 hours) (Steffen \& Löffert, 2010).

Speaking about German education institutions, where future nursing personnel may obtain specialized training, there are specialized nursing schools, namely, health and nursing care schools (Gesundheits- und Krankenpflegeschule), health and pediatric nursing care schools (Gesundheits- und Kinderkrankenpflegeschule), geriatric nursing schools (Altenpflegeschule). Usually, there is a fairly small number of students at these schools, although they may be public or state-recognized. The proximity of schools, mostly in the area of medical institutions, promotes better mastering of theory in practice, creates appropriate favourable conditions for close cooperation between schools and health facilities.

Schools assist students with their practical training (Praxisbegleitung) and provide them with practice supervisors (Praxisbegleiter) - teaching staff from a relevant nursing school. Practice supervisors should regularly attend the schools where practical training of students is conducted in order to control them and cooperate with practice mentors (Praxisanleiter). Practice mentoring (Praxisanleitung) is also provided by certain health facilities. It should be mentioned that practice mentors and supervisors, teaching staff and school administration should meet specific requirements so that nursing school may become staterecognized. For example, practice mentors should have at least a two-year experience in a particular field of care and additional professional pedagogical education (Steffen \& Löffert, 2010).

To enhance efficiency of the education process aimed at forming intellectual readiness of future specialists, teaching staff of German vocational schools should be highly qualified. Consequently, high-quality specialist training and further development of technological progress depend on professionalism of pedagogues. Therefore, the most developed direction in Germany is specialized pedagogics, i. e., a branch of professional pedagogics, which studies the problem of professional training (Abashkina, 1999).

\section{CONCLUSIONS}

The study on peculiarities of modern specialized training of nursing personnel in Germany proves it to be leading in Europe. This is facilitated by the dual model of such training organization based on priority practical studies at in-patient and out-patient 
facilities and theoretical (with elements of practical training) - at specialized nursing schools. This organization of nursing personnel training contributes to a high level of their practical training and develops core competences.

Unlike the German model of specialized training of nursing personnel, Ukrainian one dedicates less hours to their practical training. In our opinion, it is necessary to increase the number of hours for practical training. We consider it appropriate to conduct theoretical and practical studies within out-service training on different days during the week. Due to the shortage of nursing personnel in some regions, including rural areas, it is advisable to create the conditions for their undergoing practical and pre-graduation training as a prerequisite for reforming the health care system and medical education.

Rather perspective we consider further studies on didactic principles of specialized training of nursing personnel at nursing schools.

\section{REFERENCES}

1. Abashkina, N. V. (1999). Rozvytok profesiinoi osvity v Nimechchyni (kinets XIX $X X$ st.). (Avtoref. dys. d-ra ped. nauk). Instytut pedahohiky i psykholohii profesiinoi osvity APN Ukrayiny, Kyiv.

2. Bundesagentur für Arbeit. (2010). Klassifikation der Berufe - Kldb-10. Retrieved from https://statistik.arbeitsagentur.de/Statischer-Content/Grundlagen/Klassifikation-der Berufe/KldB2010/Printausgabe-KldB-2010/Generische-Publikationen/KldB2010-

Printversion-Band1.pdf.

3. Bundesagentur für Arbeit. (2017). Whitelist - Immigration into Recognized Occupations (2017). Retrieved from https://www3.arbeitsagentur.de/web/wcm/idc/groups/ public/documents/webdatei/mdaw/mta4/ edisp/L6019022DSTBAI777367.pdf.

4. Bundesinstitut für Berufsbildung. (2014). Duales Ausbildungssystem. RussischDeutsches Fachwörterbuch und Nachschlagewerk. Retrieved from http://docplayer.ru/ 36278699-Dualnaya-sistema-obucheniya-russko-nemeckiy-slovar-spravochnik-duales ausbildungssystem.html.

5. Bundesministerium der Justiz und für Verbraucherschutz. (2002). Ausbildungsund Prüfungsverordnung für den Beruf der Altenpflegerin und des Altenpflegers. Retrieved from https://www.gesetze-im-internet.de/altpflaprv/BJNR441800002.html.

6. Bundesministerium der Justiz und für Verbraucherschutz. (2003). Ausbildungsund Prüfungsverordnung für die Berufe in der Krankenpflege. Retrieved from https://www.gesetze-im-internet.de/bundesrecht/krpflaprv_2004/gesamt.pdf.

7. Bundesministerium der Justiz und für Verbraucherschutz. (2012). Fachglossar Betriebliche Ausbildung. Deutsch-Russisch. Retrieved from https://www.bmbf.de/pub/ Jobstarter_Fachglossar_russisch.pdf.

8. Bundesministerium der Justiz und für Verbraucherschutz. (2000). Gesetz über die Berufe in der Altenpflege. Retrieved from https://www.gesetze-im-internet.de/altpflg/ BJNR151310000.html.

9. Bundesministerium der Justiz und für Verbraucherschutz. (2004). Gesetz über die Berufe in der Krankenpflege. Retrieved from https://www.gesetze-im-internet.de/ krpflg_2004/_4.html.

10. Bundeszentrale für politische Bildung. (2017). Materialien zum Kapitel "Bildung". Retrieved from http://www.bpb.de/politik/grundfragen/deutsche-verhaeltnisseeinesozialkunde/139270/materialien-zum-kapitelbildung?show=image\&k. 